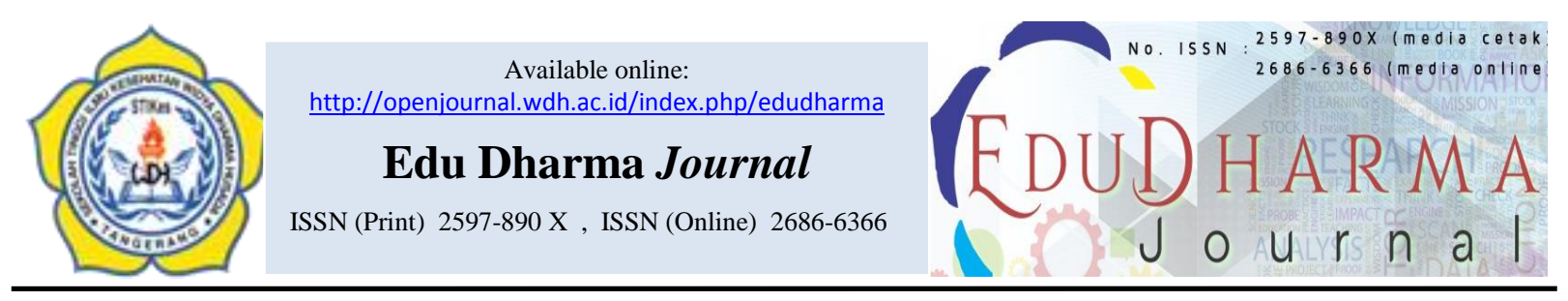

\title{
PENGARUH KANDUNGAN REBUNG DALAM MENURUNKAN KADAR KOLESTEROL DAN TEKANAN DARAH
}

Sitti Hajiyanti Makatita

Universitas Iqra Buru

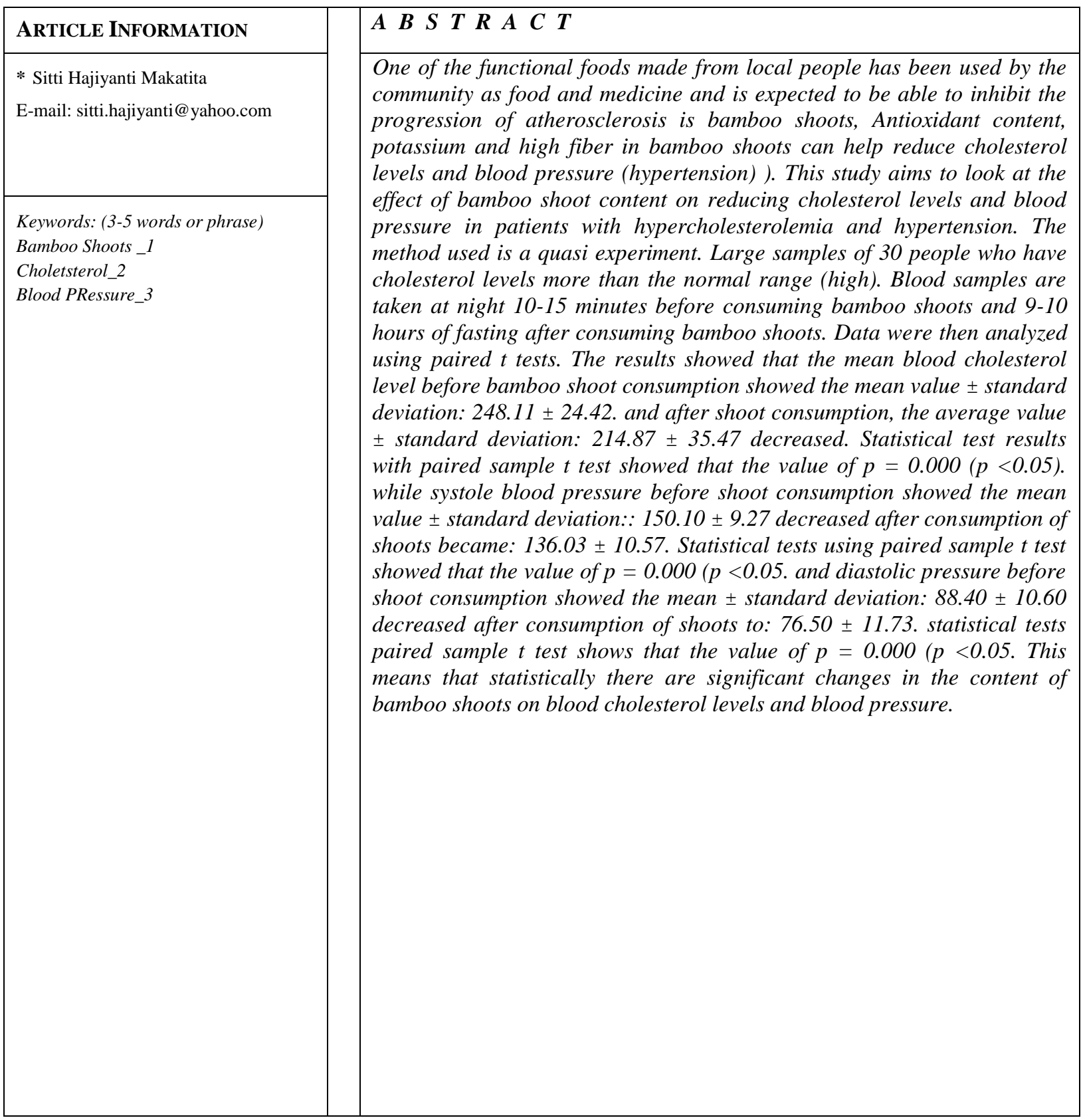




\begin{tabular}{|c|c|}
\hline \multirow[t]{3}{*}{$\begin{array}{l}\text { Kata Kunci: (3-5 kata atau frase) } \\
\text { Rebung_1 } \\
\text { Kolesterol_2 } \\
\text { Tekanan Darah_3 }\end{array}$} & $\begin{array}{l}\text { A B S T R A K } \\
\text { Salah satu bahan pangan fungsional berbahan lokal telah digunakan } \\
\text { masyarakat sebagai bahan makanan dan obat serta diperkirakan mampu } \\
\text { menghambat progresivitas aterosklerosis adalah rebung bambu (bamboo } \\
\text { shoots), Kandungan Antioksidan, kalium dan serat yang tinggi dalam } \\
\text { batang rebung mampu membantu penurunan kadar kolesterol dan tekanan } \\
\text { darah (hipertensi). Penelitian ini bertujuan untuk melihat pengaruh } \\
\text { kandungan rebung terhadap penurunan kadar kolesterol dan tekanan darah } \\
\text { pada pasien hiperkolesterol danhipertensi. Metode yang digunakan adalah } \\
\text { eksperimen kuasi. Besar sampel sebanyak } 30 \text { orang yang memiliki kadar } \\
\text { kolesterol lebih dari kisaran normal (tinggi). Sampel darah diambil pada } \\
\text { malam hari } 10-15 \text { menit sebelum mengkomsumsi rebung dan } 9-10 \text { jam } \\
\text { puasa setelah mengkomsumsi rebung. Data kemudian dianalisis dengan } \\
\text { menggunakan uji t berpasangan. Hasil penelitian menunjukkan bahwa } \\
\text { rerata kadar kolesterol darah sebelum komsumsi rebung menunjukan nilai } \\
\text { rerata } \pm \text { standar deviasi: } 248.11 \pm 24.42 \text {. dan setelah komsumsi rebung } \\
\text { mengalami penurunan dengan nilai rerata } \pm \text { standar deviasi } \\
214.87 \pm 35.47 \text {. Hasil uji statistik dengan uji paired sample } t \text { test } \\
\text { menunjukkan bahwa nilai p }=0.000 \text { (p }<0,05) \text {. sementara tekanan darah } \\
\text { sistol sebelum komsumsi rebung menunjukan nilai rerata } \pm \text { standar deviasi } \\
:: 150.10 \pm 9.27 \text { mengalami penurunan setelah komsumsi rebung menjadi }: \\
136.03 \pm 10.57 \text {. uji statistik dengan uji paired sample } t \text { test menunjukkan } \\
\text { bahwa nilai } p=0.000 \text { (p }<0,05 \text {. dan tekanan diastol sebelum komsumsi } \\
\text { rebung menunjukan nilai rerata } \pm \text { standar deviasi: } 88.40 \pm 10.60 \text { mengalami } \\
\text { penurunan setelah komsumsi rebung menjadi : } 76.50 \pm 11.73 \text {. uji statistik } \\
\text { dengan uji paired sample } t \text { test menunjukkan bahwa nilai } p=0.000 \text { (p }< \\
0,05 \text {. Hal ini berarti bahwa secara statistik terdapat perubahan yang } \\
\text { bermakna kandungan rebung terhadap kadar kolesterol darah dan tekanan } \\
\text { darah. }\end{array}$ \\
\hline & This is an open access article under the $\mathrm{CC}-\mathrm{BY}-\mathrm{NC}-\mathrm{SA}$ license. \\
\hline & () 2020 Some rights reserved \\
\hline
\end{tabular}




\section{PENDAHULUAN}

Penyakit Tidak Menular (PTM) merupakan salah satu masalah kesehatan yang telah menjadi perhatian nasional maupun global. Morbiditas dan Mortalitas PTM semakin meningkat di Indonesia. Data kematian menurut World Health Organiza-tion (WHO) tahun 2011) ${ }^{1}$, menunjukkan bahwa dari 57 juta kematian di dunia pada tahun 2008, sebanyak 36 juta disebabkan oleh PTM terdapat 582.300 laki-laki dan 481.700. Penyakit kardiovaskular merupakan PTM penyebab kematian terbesar yaitu sebesar 39\%. Kematian akibat PTM akan terus meningkat di seluruh dunia. Peningkatan terbesar akan terjadi di negara menengah dan miskin. Sebesar $70 \%$ dari populasi global akan meninggal akibat PTM seperti jantung, stroke, diabetes mellitus, kanker.

Tingginya kadar kolesterol di dalam darah merupakan permasalahan yang serius karena merupakan salah satu faktor risiko dari berbagai macam penyakit tidak menular Hasil Riskesdas tahun 2013 ${ }^{2}$ proporsi penduduk Indonesia dengan kadar kolesterol di atas normal lebih tinggi pada perempuan yaitu sebesar $39,6 \%$ jika dibandingkan dengan laki-laki sebesar $30 \%$. Kadar kolesterol yang berlebih dalam darah akan akan mudah melekat pada dinding sebelah dalam pembuluh darah.
LDL yang berlebih melalui proses oksidasi akan membentuk gumpalan yang jika gumpalan semakin membesar akan membentuk benjolan yang akan mengakibatkan penyempitan saluran pembuluh darah. Proses ini biasanya disebut dengan atheroklerosi. Aterosklerosis merupakan proses terjadinya penyempitan pembuluh darah oleh lemak dan Aterosklerosis merupakan manifestasi klinis dari penyakit jantung. , jantung akan bekerja keras untuk memompa darah, akibatnya bisa berdampak hipertensi. Bedasarkan penelitian-penelitian yang telah dilakukan risiko terjadinya ateroklerosis yang merupakan penyebab Penyakit Jantung Koroner (PJK) akan meningkat apabila kadar kolesterol total di dalam darah dan tekanan pada jantung melebihi batas normal (hipertnsi).

Hipertensi dijuluki "Silent Killer"atau si pembunuh diam-diamkarena merupakan penyakit tanpa tanda dan gejala yang khas masyarakat menganggap hipertensi hal yang biasa sehingga hanya nampak jika sudah parah dan menimbulkan komplikasi yang sangat berbahaya seperti stroke (Tarsia et al., 2013; Tolstopiatov, 2006) ${ }^{3}$. Hipertensi meningkatkan risiko penyakit jantung dua kali dan meningkatkan risiko stroke delapan kali dibanding dengan 
orang yang tidak mengalami hipertensi (Tian et al., 2011) ${ }^{4}$. Selain itu hipertensi juga menyebabkan payah jantung, gangguan pada ginjal dan retinopati. Hal ini akan membahayakan jika tidak dikontrol dengan baik.

Flora Indonesia sangat beragam jumlahnya dan mempunyai potensi yang cukup besar, Salah satu bahan pangan fungsional berbahan lokal telah digunakan masyarakat sebagai bahan makanan dan obat serta diperkirakan mampu menghambat progresivitas aterosklerosis adalah rebung bambu (bamboo shoots). Di Maluku khususnya di kabupaten Buru batang bambu muda ini sering dijadikan sebagai bahan masakan dalam pembuatan sayur. Tak hanya enak dimakan saja, batang bambu muda juga memiliki manfaat bagi kesehatan. Manfaat batang bambu muda ini tak lain karena kandungan zat yang ada di dalamnya. Kandungan Antioksidan, kalium dan serat yang tinggi dalam batang rebung mampu membantu penurunan kadar kolesterol jahat dalam tubuh tanpa mengurangi jumlah kolesterol baik. Rebung juga mengandung protein, karbohidrat, vitamin A, vitamin B6, vitamin $\mathrm{E}$ dan 12 macam asam amino yang sangat berguna bagi kesehatan tubuh (Rachmadi, 2011) ${ }^{5}$.

Antioksidan dalam rebung seperti vitamin
E, pholipenol, plavonoid, vitexin dan orientin, palmitic acid, curcumene, limonene, toluene, naphthalene, 1,3,5trimethyl benzene (Lu.B,at all, 2010) ${ }^{6}$. Senyawa antioksidan lainnya yang ada didalam rebung bambu adalah vitamin $\mathrm{A}$, thiamin, riboflavin, vitamin $\mathrm{C}$, kurkumin (Choudhury.D at all, 2010) ${ }^{7}$. Semua kandungan Antioksidan yang terkandung dalam batang rebung termasuk dalam jenis fikosterol. Antioksidan jenis ini mampu membantu penurunan kadar kolesterol jahat dalam tubuh tanpa mengurangi jumlah kolesterol baik. Antioksidan yang ada pada batang rebung juga mampu melindungi sel dari kerusakan. Selain itu, kandungan protein dan di dalamnya juga akan membantu sel tetap sehat. Selain itu kandungan kalium dan serat yang tinggi dalam rebung juga mampu menurunkan kadar kolesterol darah. Kadar Kalium ini juga dapat menurunkan tekanan darah ke jantung karena mampu mengurangi desakan aliran darah, sehingga dapat menjaga kesehatan jantung dan memperkecil resiko serangan jantung koroner dan penyakit strok.

Meskipun banyak kandungan manfaat dari rebung, sampai saat ini masih sedikit masyarakat yang mengetahui manfaat dan mengkonsumsinya serta kurangnya informasi ilmiah dalam aplikasi terhadap 
manusia.. Sehubungan dengan itu maka penelitian ini bertujuan untuk melihat pengaruh kandungan rebung dalam menurunan kadar kolesterol dan tekanan darah.

\section{METODE PENELITIAN}

Penelitian ini merupakan penelitian dengan pendekatan longitudional yang menggunakan desain penelitian quasy eksperiment, dengan rancangan group pretest, post-test design. semua data kadar kolesterol dan hipertensi yang dibutuhkan akan dikumpulkan dalam dua waktu, yaitu : sebelum dan setelah mengkomsumsi rebung.

Penelitian ini telah dilaksanakan pada bulan april-Mei 2019 yang diawali dengan pengumpulan sampel hingga terpenuhinya jumlah sampel. Pengambilan sampel darah akan dilakukan di lokasi penelitian kota namlea. Populasi dalam penelitian ini adalah masyarakat dewasa berumur $>30$ tahun yang memiliki riwayat kolesterol tinggi dan berdomisili di kota Namlea. Sampel merupakan bagian populasi yang akan diteliti atau sebagian jumlah dari karakteristik yang dimiliki oleh populasi (Hidayat, 2007) ${ }^{8}$. Teknik pengambilan sampel dilakukan dengan menggunakan purposive sampling, yaitu teknik pengambilan sampel yang didasarkan pada suatu pertimbangan tertentu yang dibuat oleh peneliti sendiri, berdasarkan ciri atau sifat-sifat populasi yang sudah diketahui sebelumnya (Notoatmodjo, 2012) ${ }^{9}$. Stelah dilakukan pendataan awal dan dilakukan pengukuran, jumlah sampel yang ditetapkan sebanyak 30 orang terdiri dari 12 laki-laki dan 18 perembuan. Variabel bebas/ independent variabel (X), yaitu: Kandungan Rebung, sedangkan Variabel terikat/ dependent variabel (Y), yaitu: Kadar Kolesterol dan tekanan darah. Pengukuran kadar kolesterol dilakukan dengan menggunakan alat cek kolestrol dan stetoskop untuk tekanan darah dengan

Pengumpulan data kadar kolesteol dan hipertensi dilakukan 10-15 menit sebelum komsumsi rebung antara pukul 22:0023:00, setelahnya subjek tidak diperkenankan untuk makan maupun minum (puasa), subjek bahkan tidak boleh melakukan aktifitas fisik sedang maupun berat (istirahat) sebelum pengukuran berikutnya. Pengukuran kadar kolesterol dan hipertensi 9-10 jam setelah makan rebung antara pukul 07:00-08:00. Pengambilan dan pengukuran dilakukan oleh tenaga ahli

\section{Prosedur Kerja}

Tahap 1

1. Melakukan pendataan dan wawancara bebas untuk memperoleh informasi 
dan keadaan umum responden, meliputi umur, dan riwayat penyakit.

2. Mengumpulkan responden yang memenuhi kriteria.

3. Menjelaskan prosedur penelitian kepada responden.

4. Meminta untuk menandatangani lembar persetujuan menjadi responden.

Tahap 2

1. Melakukan pengukuran pertama yaitu : pengukuran kadar kolesterol dan tekanan darah responden 10-15 menit sebelum komsumsi rebung dengan mnggunakan alat cek kolesterol (nesco), dan hipertensi dengan tensi electrik.

2. Responden kemudian diberi makan rebung dan beristirahat selama 9-10 jam serta tidak diperbolehkan makan

3. Melakukan pengukuran berikutnya 910 jam setelah mengkosumsi rebung.

4. Melakukan perbandingan hasil analisis kadar kolesterol sebelum dan setelah mengkomsumsi rebung.

Analisis data dilakukan dengan menggunakan uji $\mathrm{t}$ berpasangan untuk menentukan pengaruh variabel independen terhadap variabel dependen, jika data berdistribusi normal dan uji Wilcoxon jika data tidak berdistribusi normal dengan nilai kemaknaan $\mathrm{p}<0,05$ dengan

menggunakan program komputer SPSS 23.0.

\section{HASIL}

Tabel 1. Karakteristik Responden penelitian

\begin{tabular}{lll}
\multicolumn{1}{l}{$(\mathrm{n}=30)$} & & \\
\hline $\begin{array}{l}\text { Karakteristik } \\
\text { Responden }\end{array}$ & Jumlah & $\%$ \\
\hline $\begin{array}{l}\text { Jenis Kelamin: } \\
\text { Laki-laki }\end{array}$ & 12 & 40 \\
Prempuan & 18 & 60 \\
\hline Usia (Tahun) : & & \\
$30-39$ & 10 & 33,3 \\
$40-49$ & 10 & 33,3 \\
$50-59$ & 5 & 16,6 \\
$60-69$ & 5 & 16,6 \\
\hline
\end{tabular}

Sumber : Data primer, 2019

Dari Tabel 1. Dapat dilihat jumlaht subjek pada penelitian sebanyak 30 0rang yang memiliki kadar kolesterol dan tekanan darah melebihi kisaran normal (tinggi) : terdiri dari 12 orang laki-laki (40\%) dan 18 orang perempuan $(60 \%)$, dengan rentang usia 30-39 sebanyak 10 orang (33.3\%), 4049 sebanyak 10 orang (33.3\%), 50-59 sebanyak 5 orang (16.6\%), dan 60-69 sebanyak 5 orang $(16.6 \%)$

Tabel 2. Perubahan kadar kolesterol darah sebelum dan setelah komsumsi rebung.

\begin{tabular}{llll}
\hline $\begin{array}{l}\text { Kadar } \\
\text { kolesterol } \\
\text { darah }\end{array}$ & $\begin{array}{l}\text { Mean } \\
(\mathrm{SD})\end{array}$ & $\begin{array}{l}\text { Selisih } \\
(\mathrm{SD})\end{array}$ & $\mathrm{P}^{*}$ \\
\hline Sebelum & $\begin{array}{l}248,11 \\
(24 ., 2)\end{array}$ & $\begin{array}{l}33,07 \\
(30,33)\end{array}$ & 0,000 \\
& & & \\
Setelah & 214,87 & \\
\multicolumn{4}{l}{ Sumber : uji statistik } \\
\hline
\end{tabular}


Dari Tabel 2. dapat dilihat bahwa kadar kolesterol darah sebelum komsumsi rebung menunjukan nilai rerata \pm standar deviasi: 248.11 \pm 24.42 . Sementara setelah komsumsi rebung mengalami penurunan dengan nilai rerata \pm standar deviasi : 214.87 \pm 35.47 . Hasil uji statistik dengan uji paired sample $t$ test menunjukkan bahwa nilai $\mathrm{p}=0.000(\mathrm{p}<0,05)$ yang berarti bahwa ada pengaruh yang signifikan pengaruh kandungan rebung terhadap penurunan kadar kolesterol darah. Hasilnya terlihat juga pada gambar grafik 1

Tabel 3. Perubahan Tekanan Darah Sebelum dan Setelah Komsumsi Rebung

\begin{tabular}{llcc}
\hline Tekanan Darah & Mean (SD) & Selisih (SD) & P* \\
\hline Sistol sebelum & $150.10(9.27)$ & $14.07(6.39)$ & 0.000 \\
Sistol setelah & $136.03(10.57)$ & $11.97(10.27)$ & 0.000 \\
\hline Distol sebelum & $88.40(10.60)$ & & \\
Distol setelah & $76.50(11.73)$ & & \\
\hline
\end{tabular}

Sumber : uji statistik paired sampel T-tes

Tabel 3. memperlihatkan rerata tekanan sistol sebelum 150.10 (9.27) mengalami penurunan menjadi 136.03 (10.57), rerata diastol sebelum $88.40 \quad(10.60)$ juga mengalami penurunan menjadi 76.50 (11.73). Hasil uji statistik dengan uji paired sampel T-tes menunjukkan bahwa nilai $\mathrm{p}$ tekanan sistol $=0.000(\mathrm{p}<0,05)$.
Hasil uji statistik dengan uji paired sampel T-tes menunjukkan bahwa nilai $\mathrm{p}$ tekanan diastol $=0.000(\mathrm{p}<0,05)$. Hal ini berarti ada pengaruh yang signifikan kandungan rebung terhadap penurunan tekanan darah tinggi (hipertensi). Hasilnya terlihat juga pada gambar grafik 2. 


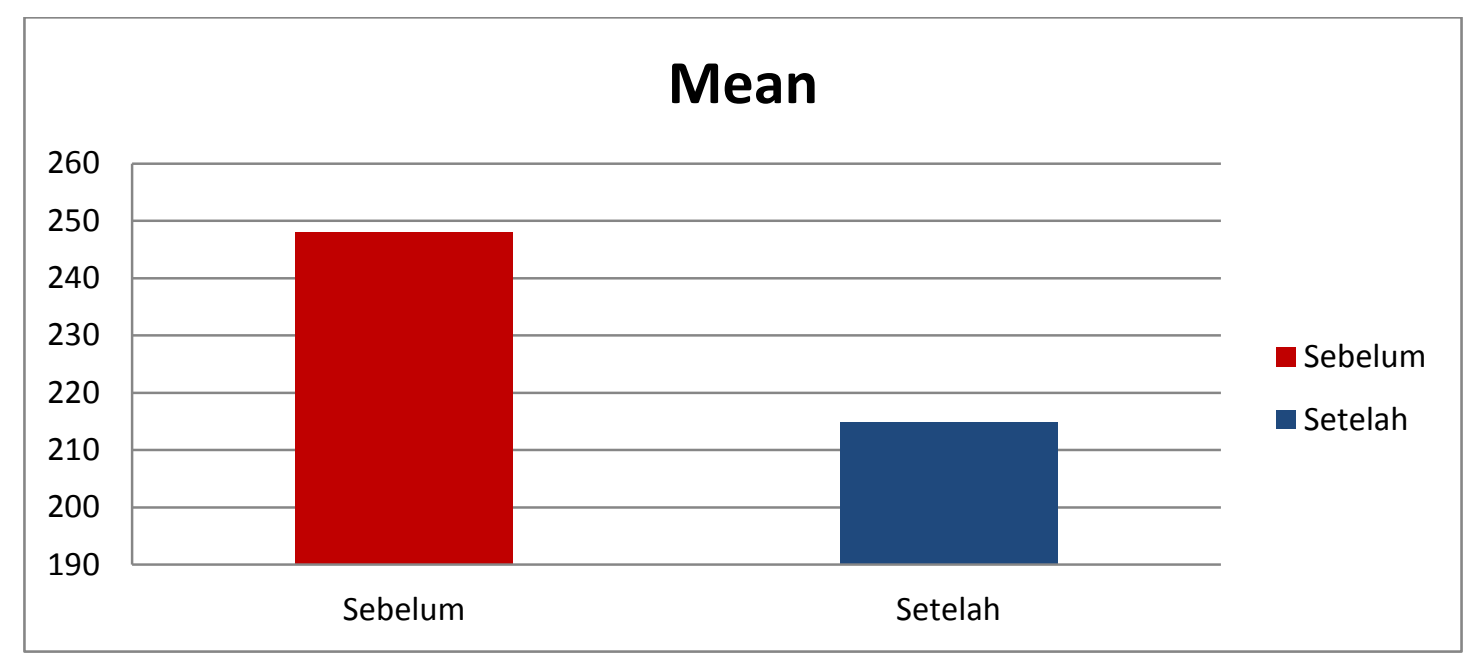

Grafik1. Diagram batang perubahan kadar kolesterol darah sebelum dan setelah komsumsi rebung

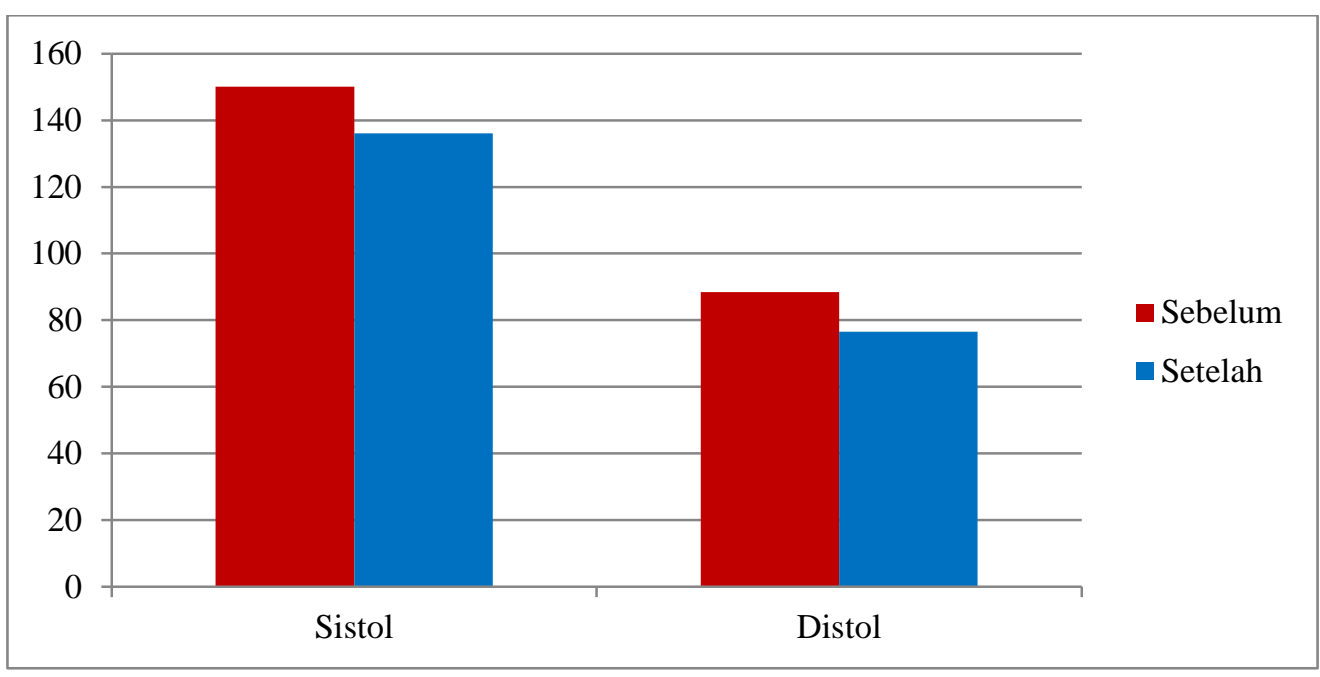

Grafik 2. Diagram batang perubahan tekanan darah sebelum dan setelah komsumsi rebung

\section{PEMBAHASAN}

Penelitian ini memperlihatkan adanya pengaruh kandungan rebung terhadap penurunan kadar kolesterol darah dan tekana darah, dan telah dilaksanakan di Namlea, pada bulan April - Mei 2019. Subjek penelitian berjumlah 30 orang individu dewasa berusia $>30$ tahun. Semua subjek penelitian diukur kadar kolesterol dan tekanan darah sebanyak dua kali yakni sebelum makan rebung dan 9-10 jam setelah makan rebung. Karakteristik responden dapat dilihat pada tabel 1 .

Dari hasil analisis menunjukan adanya pengaruh yang signifikan kandungan rebung dalam menurunkan kadar kolosterol darah. Hal ini sesuai dengan 
penelitian Iskiana Noviawati (2012) ${ }^{10}$, pada penelitiannya yang menunjukkan bahwa pemberian ekstrak tunas bambu ater berpengaruh menurunkan kadar kolesterol darah tikus putih. Hasil Penelitian Edy soesanto (2017) juga membuktikan pengaruh ekstrat rebung babu apus dapat menurunkan kadar MDA pada kelinci new-zaeland white hiprkolesterolemia.

Rebung bambu dipercaya dapat menurunkan kadar kolesterol darah, obat sakit kuning/lever (sirosis hati), obat bengkak, batuk berdahak dan demam (Edy soesanto, 2018) ${ }^{11}$. hal ini didukung dengan hasil studi yang mnyatakan bahwa dengan mengonsumsi rebung setiap hari, kadar kolesterol akan turun sebanyak $23 \%$. Pernyataan yang sama oleh penelitian Park Eun Jin bahwa mengonsumsi $360 \mathrm{~g}$ rebung setiap hari akan menurunkan kolesterol total sebesar 3,9 mg/dl dan kolesterol LDL $16,1 \mathrm{mg} / \mathrm{dl}$.

Rebung mengandung nutrisi yang tinggi. Rebung mengandung antioksidan, serat (karbohidrat kompleks), lemak, protein, vitamin $\mathrm{A}$, thiamin, riboflavin, vitamin $\mathrm{C}$, serta serta mineral lain seperti kalsium, fosfor, besi, dan kalium. Kandungan kalium dalam rebung cukup tinggi, yaitu $533 \mathrm{mg}$ per 100 gram rebung.

Kandungan Antioksidan yang terkandung dalam batang rebung termasuk dalam jenis fikosterol. Antioksidan jenis ini mampu membantu penurunan kadar kolesterol jahat dalam tubuh tanpa mengurangi jumlah kolesterol baik. Antioksidan yang ada pada batang rebung juga mampu melindungi sel dari kerusakan. Selain itu kandungan kalium dan serat yang tinggi dalam rebung juga mampu menurunkan kadar kolesterol darah. kandungan serat pangan rebung lumayan tinggi: yakni 2,56 persen, lebih tinggi bila dibandingkan dengan jenis sayuran tropis lainnya, seperti kecambah kedelai (1,27 persen), pecay $(1,58)$, ketimun $(0,61)$, dan sawi $(1,01)$. Serat pangan adalah senyawa berbentuk karbohidrat kompleks yang banyak terdapat pada dinding sel tanaman pangan. Serat pangan tidak dapat dicerna dan diserap oleh saluran pencernaan manusia, tetapi berfungsi penting bagi pemeliharaan kesehatan, pencegahan penyakit, dan sebagai komponen penting dalam terapi gizi.

(https://www.liputan6.com/health/read/227 0523/lezatnya-rebung-yang-kaya-seratdan-penurun-kolesterol)

Serat rebung yang mengandung lignin (insoluble fiber), pectin dan glucans (soluble fiber) mempunyai efek mengikat zat-zat organik seperti asam empedu dan kolesterol sehingga dapat menurunkan 
jumlah asam lemak di dalam saluran pencernaan . Pengikatan empedu oleh serat juga menyebabkan asam empedu keluar dari siklus enterohepatik, karena asam empedu yang disekresi ke usus tak dapat diabsorbsi tetapi terbuang ke dalam feses. Penurunan jumlah asam empedu menyebabkan hepar harus menggunakan kolesterol sebagai bahan untuk membentuk asam empedu. Hal ini yang menyebabkan serat dapat menurunkan kadar kolesterol. Diduga pula bahwa dengan keberadaan serat akan menghambat emulsifikasi lemak dan kolesterol oleh garam empedu, sehingga kolesterol akan terikat oleh serat yang kemudian akan dikeluarkan melalui ekskreta.

Penelitian (Kurniasari, 2014) ${ }^{12}$ menyatakan bahwa ada hubungan antara asupan serat dengan trigliserida dalam darah. Semakin rendah asupan Serat, maka semakin tinggi kadar kolesterol total dan semakin tinggi asupan Serat semakin rendah kadar glukosa dan trigliserida darah hal ini menunjukkan ada hubungan asupan serat dengan penyakit diabetes dan kardiovaskular karena pengaruh dari kadar kolesterol dan glukosa yang dapat memicu peningkatan penyakit tersebut bila dikonsumsi secara berlebih tetapi asupan serat dapat membantu menurutkan kadar kolesterol, trigliserida dan kadar gula dalam darah

Penelitian sama juga dilakukan oleh Purdue University yang mengemukakan bahwa kemampuan rebung dalam menurunkan kolesterol berhubungan dengan kandungan serat beta-glukan yang mampu mencegah penempelan plak kolesterol dalam pembuluh darah dan kemudian membuangnya bersama kotoran. Rebung merupakan salah satu sumber pangan yang memiliki serat yang cukup tinggi. Serat pangan adalah makanan berbentuk karbohidrat kompleks yang banyak terdapat pada dinding sel tanaman pangan. Serat pangan tidak dapat dicerna dan tidak diserap oleh saluran pencernaan manusia, tetapi memiliki fungsi yang sangat penting bagi pemeliharaan kesehatan, pencegahan penyakit dan sebagai komponen penting dalam terapi gizi. Serat rebung yang mengandung lignin (insoluble fiber), pectin dan glucans (soluble fiber) mempunyai efek mengikat zat-zat organik seperti asam empedu dan kolesterol sehingga menurunkan jumlah asam lemak di dalam saluran pencernaan.

Dari Hasil penelitian ini juga memperlihatkan adanya pengaruh yang signifikan kandungan rebung dalam menurunkan tekanan darah baik sistol maupun distol. Berdasarkan penelitian sebelumnya terhadap evaluasi aktivitas 
antihipertensi pada rebung bambu jenis Phyllostachys pubescens, dalam pengujian antihipertensi pada tikus Sprague-Dawley dari hasilnya diproleh mampu menurunkan tekanan darah pada tikus yang hipertensi (Lianliang et al 2012) ${ }^{13}$. Penelitian yang sama juga dilakukan oleh Muhamad Ilham R (2018) Hasil penelitiannya menunjukkan pemberian ekstrak etanol rebung bambu tali mempunyai aktifitas antihipertensi terhadap tikus putih jantan SpragueDawley yang diinduksi prednison dan $\mathrm{NaCl}$.

Menurunnya tekanan sistol maupun diastol jantung setelah komsumsi rebung dikarenakan respon tubuh akibat pengaruh zat antioksidan yang terkandung didalam rebung. Kaliumnya yang tinggi dan pithopenolnya merupakan antioksidan (Parekh. J and Chanda.S, 2007) ${ }^{14}$. Selain itu, kandungan potassium dalam rebung bisa menurunkan tekanan darah tinggi, juga memperlancar peredaran darah (https://food.detik.com/info-sehat/d-

$\underline{1890135 / \text { serat-tinggi-rebung-efektif- }}$

turunkan-kolesterol $^{16}$. Ada juga kandungan anti oksidan dan anti inflamasi yang membantu tubuh mencegah berbagai penyakit. Sebuah penelitian di Jepang juga menemukan bahwa rebung memiliki kandungan anti kanker dan bisa mencegah radikal bebas yang berbahaya bagi tubuh.

Rebung bambu mengandung beberapa zat aktif yaitu saponin, flavonoid, dan polifenol. Flavonoid secara umum berperan sebagai agen protektif terhadap penyakit-penyakit tertentu karena mempunyai beberapa sifat oksidatif. Kandungan dan aktivitas oksidatif flavonoid sebagai salah satu kelompok antioksidan alami dari suatu tanaman. Saponin secara umum mempunyai aktivitas biologi yang cukup luas, diantaranya sebagai immunomodulator, anti tumor, anti inflamasi, dan antioksidan. Senyawa yang mempunyai aktivitas biologis sebagai diuretik adalah flavonoid. Mekanisme kerja flavonoid sebagai diuretik yaitu dengan menghambat reabsorpsi $\mathrm{Na}+, \mathrm{K}+$ dan Clsehingga terjadi peningkatan elektrolit di tubulus sehingga terjadilah diuresis. Diuresis menyebabkan penurunan volume plasma yang akan menurunkan curah jantung dan akhirnya menurunkan tekanan darah (Latuconsina et al 2014; Kurniawati 2015) ${ }^{15}$.

\section{KESIMPULAN}

Berdasarkan hasil penelitian, maka dapat disimpulkan bahwa : Terdapat pengaruh yang bermakna kandungan rebung dalam penurunan kadar kolesterol dan tekanan darah. 


\section{DAFTAR PUSTAKA}

Choudhury.D, Jatindra K. Sahu.J.K, and Sharma.G.D.Biochemistry of bitterness in bamboo shoots. Assam University Journal of Science \& Technology : Physical Sciences and Technology. 2010; 6; II: 105-111

Edi soesanto dan khoiriah (2017). Efektifitas ekstrat rebung babu apus terhadap penurunan kadar MDA pada kelinci new zaeland white hiperkholesterolemia.

Hidayat, A.A. 2007. Metode Penelitian Kebidanan Teknik Analisa Data. Penerbit Salemba Medika. Jakarta

Kementrian K. Profil Kesehatan Dasar Tahun 2013. Jakarta: Kementrian Kesehatan RI; 2014.

Kurniasari, R. (2014). Hubungan Asupan Karbohidrat, Lemak, dan Serat dengan Kadar Glukosa dan Trigliserida Darah Pada Pasien DM Tipe II Rawat Inap Di RSUP H.Adam Malik Medan. Wahana Inovasi, 3(1), 1-5.

Kurniawati E. 2015. Daya Antibakteri Ekstrak Etanol Tunas Bambu Apus Terhadap Bakteri Escherichia Coli dan Staphylococcus Aureus Secara In Vitro. Jurnal Wiyata 2:193-199

Lianliang L, Lingyi L, Baiyi L, Daozong, dan Ying Z. 2012. Evaluation of Antihypertensive Antihyperlipidemic Effects of Bamboo Shoot Angiotensin Converting Enzyme Inhibitory Peptide in Vivo. Journal of Agricultural and Food Chemistry 60:11351-1135
Lu.B, Xia.D, Huang.W, Wu.X, Zhang.Y, Yao.Y. Hypolipidemic effect of bamboo shoot oil (P. pubescens) in Sprague-Dawley rats .Article first published online Institute of Food Technologists. 2010: 1750-3841

Notoatmodjo, Soekidjo. 2012. Metodologi Penelitian Kesehatan. Rineka Cipta. Jakarta

Parekh.J and Chanda.S. 2007. In vitro antibacterial activity of the crude methanol extract of woodfordia fruticosa kurz flower (lythraceae).Brazillian.J. Microbial. ; $38: 204-207$.

Rachmadi, A.T. 2011. Pemanfaatan fermentasi rebung untuk bahan suplemen pangan dan tepung serat. Jurnal Riset Industri Hasil Hutan 3(1):37-41.

Tarsia, J., Chang, T. R., Aysenne, A., Boehme,A. K., Sartor, A. E., Albright, K. C., . . Martin-Schild, S. (2013). Elevated Plasma Factor VIII in Patients with Ischemic Stroke: Does it have any Association with Hypertensive Heart Disease? Journal Of Neurological Disorders \& Stroke, 1(3), 1027-1027

Tian, Z., Liu, Y.-T., Fang, Q., Ni, C., Chen, T.-B., Fang, L.-G., . . . Zeng, X.-F. (2011). Hemodynamic parameters obtained by transthoracic echocardiography and right heart catheterization: a comparative study in patients with pulmonary hypertension. Chinese Medical Journal, 124(12), 1796-1801. 